\title{
FAKTOR YANG MEMPENGARUHI \\ KETERLAMBATAN PERIKSA PADA PENDERITA KANKER SERVIKS (Studi Kasus di RSUD Sidoarjo)
}

\author{
Yefi Marliandiani, SST ${ }^{\mathbf{1}}$. Retno Setyo Iswati, SST $^{\mathbf{2}}$ \\ Prodi D-III Kebidanan Universitas PGRI Adi Buana Surabaya \\ yefigunawan@yahoo.com
}

\begin{abstract}
ABSTRAK
Carcinoma Cervix adalah keganasan dari sel-sel neoplasma servix yang timbul di batas antara epitel yang melapisi endoservix (porsio dan endoserviks) yang disebut Squamo Columnar Juction. Pada awal perkembangan Carcinoma Cervix tidak memberi tanda-tanda dan keluhan. Penyakit ini bermula sebagai proses dysplasia pada sambungan squamosa kolumnar. Kemajuan yang berlangsung dari dysplasia berat dan karsinoma Insitu memakan waktu bertahun-tahun. Sebagian pasien mengalami tranformasi cepat dan sebagian pasien displasianya akan menghilang tanpa pengobatan. Waktu ratarata yang diperlukan untuk berkembang menjadi kanker invasif sejak awal mengalami dysplasia adalah 10-20 tahun. Penelitian ini bertujuan mengetahui Faktor Yang Mempengaruhi Keterlambatan Periksa Pada Penderita Kanker Serviks.

Dalam penelitian digunakan metode deskriptif dengan desain penelitian yang pengambilan sampelnya dilakukan secara non probability sampling dan tipe yang digumakan adalah porposive dengan menggunakan kuesioner.

Berdasarkan hasil penelitian yang telah dilakukan diperoleh hasil bahwa dari 30 responden, sebagian besar 16 orang $(53,33 \%)$ memiliki pengetahuan kurang. sebagian besar 14 orang $(46,67 \%)$ tergolong pendapatan rendah. Maka dapat disimpulkan faktor yang lebih mempengaruhi adalah pengetahuan. Oleh sebab itu perlu adanya penyuluhan tentang kanker serviks, dan dapat disimpulkan bahwa terdapat pengaruh antara tingkat pengetahuan dan tingkat pendapatan dengan kanker serviks dengan menggunakan uji chi-square dengan taraf signifikan $\alpha=0,05$
\end{abstract}

Kata Kunci : Terlambat Periksa, kanker serviks

\section{PENDAHULUAN}

Tujuan pembangunan kesehatan

adalah untuk meningkatkan kesadaran,

kemauan dan kemampuan untuk sehat bagi

setiap orang agar terwujud derajat

kesehatan masyarakat yang optimal.

Tujuan pembangunan di Indonesia

memberi dampak pada bergesernya pola penyakit. Selain penyakit infeksi, saat ini

Indonesia dihadapkan pada penyakit tidak menular seperti kardiovascular, diabetes, gangguan jiwa dan kanker.

Diantara penyakit non infeksi, kanker merupakan masalah yang terus meningkat baik di Negara berkembang maupun Negara maju. Kanker merupakan 
penyakit yang banyak diderita masyarakat indonesia dan diperkirakan terus bertambah. Badan Kesehatan Dunia (WHO) mengatakan, saat ini penyakit kanker serviks menempati peringkat teratas di antara berbagai jenis kanker yang menyebabkan kematian pada perempuan di indonesia.

$$
\text { Di Indonesia, setiap tahun }
$$
terdeteksi lebih dari 15.000 kasus kanker serviks. Sekitar 8000 kasus di antaranya berakhir dengan kematian. Menurut WHO, Indonesia merupakan negara dengan jumlah penderita kanker serviks yang tertinggi di dunia. Data terbaru berdasarkan penelitian pada 13 laboratorium Patologi Anatomi di seluruh Indonesia menempatkan kanker serviks di urutan pertama dengan prevalensi 18,62 $\%$, disusul kanker payudara 11,22 \% dan kanker kulit 8,30\%.

\section{Menurut Fredrico Patria, Ketua}

Pelaksana Inisiatif Pencegahan Kanker Serviks Indonesia (IPKASI), bahwa gejala awal kanker serviks sulit dideteksi. Pada umumnya perempuan Indonesia memeriksakan dirinya saat sudah terkena stadium lanjut sehingga menyebabkan kematian. Artinya, kanker serviks menimbulkan beban kesehatan, ekonomi dan sosial.

Pencegahan kanker serviks melalui pencegahan primer yaitu informasi dan vaksinasi, dan pencegahan sekunder yakni deteksi dini melalui pap smear atau IVA. Vaksinasi yang dilakukan bersamaan dengan deteksi dini dipercaya dapat menurunkan angka kanker serviks.

\section{METODE}

Desain penelitian ini menggunakan desain penelitian deskriptif yaitu suatu metode penelitian yang dilakukan dengan tujuan utama untuk membuat gambaran tentang faktor yang mempengaruhi keterlambatan periksa pada penderita kanker serviks. Pengambilan data dilakukan di poli kandungan RSUD Sidoarjo pada bulan November 2011. Populasi penelitian ini adalah semua 
pasien yang berkunjung ke poli kandungan

RSUD Sidoarjo pada bulan November

2011 yang menderita kanker serviks ada

76 orang. Sampel dalam penelitian ini adalah pasien yang berkunjung ke poli kandungan RSUD Sidoarjo pada bulan November 2011 yang didiagnosa kanker serviks stadium II, III, dan IV berjumlah 30 orang, pemilihan sampel diambil dengan cara Nonprobability sampling dengan teknik Purposive Sampling.

\section{HASIL PENELITIAN}

Berdasarkan penelitian didapatkan bahwa dari $30 \mathrm{ibu}$ penderita kanker serviks, sebagian besar 16 orang $(53,33 \%)$ memiliki pengetahuan kurang. Kurangnya pengetahuan penderita kanker serviks memperlambat untuk memeriksakan dirinya. Pendidikan dapat membawa wawasan atau pengetahuan seseorang. Secara umum, seorang yang berpendidikan lebih tinggi akan mempunyai pengetahuan yang lebih luas dibandingkan dengan seseorang yang tingkat pendidikannya lebih rendah.

Dari 30 ibu penderita kanker serviks , sebagian besar 14 orang $(46,67$ $\%$ tergolong pendapatan rendah. Pendapatan adalah sesuatu yang didapatkan dan sebelumnya belum ada. Pendapatan erat sekali dengan status kesehatan. Pendapatan rumah tangga yaitu gabungan dari seluruh upah / gaji yang diterima oleh seluruh anggota rumah tangga yang bersangkutan. Masyarakat kurang mampu memang seringkali mengalami kesulitan dalam mengakses pelayanan kesehatan. Hal ini dikarenakan tidak adanya kemampuan secara ekonomi dikarenakan biaya kesehatan memang mahal.

Hasil penelitian dapat disimpulkan bahwa terdapat pengaruh antara tingkat pengetahuan dan tingkat pendapatan dengan kanker serviks dengan menggunakan uji chi-square dengan taraf signifikan $\alpha=0,05$ 




